Miroslava Ťavodová

Associate Professor

Technical University in Zvolen

Faculty of Technology

Slovakia

Nataša Náprstková

Associate Professor

Jan Evangelista Purkyně University in Ústí nad Labem

Faculty of Mechanical Engineering Czech Republic

Michaela Hnilicová

Assistant Professor Technical University in ZvolenFaculty of Technology Slovakia

Pavel Beňo

Associate Professor Technical University in Zvolen

Faculty of Technology Slovakia

\section{Quality Evaluation of Welding Joints by Different Methods}

This paper presents the results of the quality evaluation of the weld joints on welded pipes used in industrial energy. The quality evaluation of the weld joints was performed by two methods. Using technical methods, welding faults and defects were examined, identified and evaluated by a metallographic analysis on the macrostructure of welds. According to ISO 6520-1:2007, the faults and defects were detected and classified into the group and classified into quality levels using ISO 5817:2008-03. Two quality management tools using a Cause and effect diagram - Iskihawa diagram and a Pareto diagram also evaluated the quality control of welds. These two tools enabled to identify the causes of welding defects as well as to determine the frequency of their occurrence and to identify the most serious welding faults and defects. Both methods - technical and management, should reveal shortcomings in both technical, technological and personnel aspect. Their use should contribute to improving the welding process of pipes in operation and to increasing the safety of piping systems.

Keywords: quality, weld joints of the pipes, welding defects Pareto diagram, Ishikawa diagram.

\section{INTRODUCTION}

The term product quality is said to be the oldest economic, but also technical and technological category. Quality is not only a term for product's characteristics, but also for the people who create this product and use it correctly in practice [1].

The quality of weld product should not be limited to its final inspection, but it should include all process proposals [2] and production strategies [3]. According to the authors [1-4], the product price consists of a combination of several different items.

Between them, time needed for an adequate control of the product can be one of the most significant items, which can get expensive. In addition, verification of the quality of welding processes is not easy and therefore the specification of welding quality and inspection requirements is very important. It is necessary to ensure control of the whole process.

Starting with the control of personnel qualification, engineering design, selection of materials (basic [5] and welding [6]), the control of supplies, production documentation, workplaces and welding equipment, preparation and the actual welding process, possible repairs, until to a specific control of weld joints and weld deposits and the control of heat treatment of welded products.

\section{MATERIAL AND METHODS}

Welding is a process in which un-dismountable con-

Received: June 2020, Accepted: August 2020

Correspondence to: Dr. Eng. Miroslava Ťavodová, PhD.

Faculty of Technology, Technical University in Zvolen

Študentská 26, 96001 Zvolen, Slovakia

E-mail: tavodova@tuzvo.sk

doi: $10.5937 /$ fme2004816T

(C) Faculty of Mechanical Engineering, Belgrade. All rights reserved nections are formed by the inter-atomic bonds between the welded parts during its heating or plastic deformation, respectively by the action of both. It is an undismountable metallurgical joining of two or more materials of the same or different composition [6].

The most used welding methods are based on melting of materials at the point of contact of the joined parts. In fusion welding, the metal is melted by a heat source and a metallurgical bonding occurs. There are many welding processes and methods. None of them is universally the best. Each one has specific advantages and corresponds to the type of use. The molten weld metal must be protected from the surrounding atmosphere because the absorption of oxygen and nitrogen leads to poor, often unsatisfactory weld quality. Therefore, a specified gas at the weld site must replace the air or the weld must be protected by a flux. The molten metal is therefore usually protected by a gaseous protective atmosphere or slag flux.

Manual Metal Arc Welding (MMAW), commonly called covered electrode welding, is welding method characterized by specific features. The heat for welding is generated by an electric arc established between the end of the electrode and the near surface of the welding material. The additional material - a covered electrode consisting of a metal core and a flux coating is gradually melted in the form of droplets. It passes into the weld pool forming a substantial proportion of the weld metal. The direction of welding and guidance of the electrode is performed manually by a welder. The electric arc in energetically doped by a source of electric voltage - a welding source - which must have specific properties. The covered electrode consists of a metal core. It is a drawn wire (cast rod or pressed metal power rarely), which is coated with a specific coating ensuring the stability and protection of the electric arc and the protection of the weld metal from air gases. The 
welding process begins with the formation ("ignition") of an electric arc at the start of welding. It continues without interruption until the entire length of the electrode has melted or the required amount of weld metal has been melted. The electrode melts gradually. The melting rate of the electrode is depending on the intensity of the welding current. The transfer of weld metal through the arc takes place in the form of small droplets. The advantages of MMAW are high quality of the weld joints, the widest range of filler materials for all groups of welded materials, maximum flexibility and speed of deployment, availability and relatively low dependence on environmental influences, versatility and usability even in the most complicated situations and positions, high reliability during implementation and lower investment costs. The disadvantages of this method are lower productivity compared to MIG, MAG and TIG methods, possibility of increased error rate such as e.g. porosity, the need to remove slag, the impossibility of automation and mechanization, an increased percentage of harmful substances and lower occupational hygiene. Figure 1 shows the principle of MMAW [6,7].

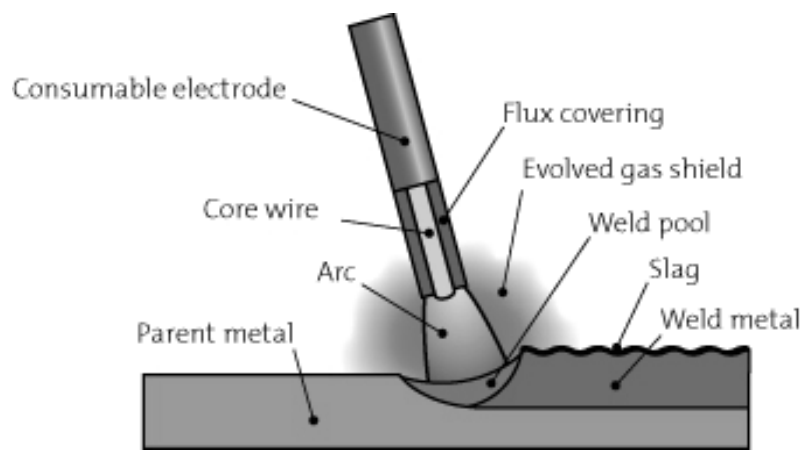

Figure 1. MMAW process

Tungsten Inert Gas (TIG) welding uses the heat generated by a welding arc struck between a nonconsumable electrode (using a non-consumable electrode made of pure or activated tungsten) and welded material. The arc area and welding bath are shrouded in an inert shielding gas - argon or helium and their mixtures. It flows from the ceramic nozzle of the TIG torch and prevents atmospheric oxidation of the weld. When welding thicker thicknesses (up to $3 \mathrm{~mm}$ ) and when hard facing, filler in the form of a rod, a wire or filled electrode is added to the arc. With contactless HF ignition of the welding arc, the wolfram electrode always remains in a spaced-apart relationship to the welded material, and a high-frequency high voltage is applied between them. Contact LIFT ignition of the welding arc involves the slight relifting of the wolfram electrode from the welded material under the simultaneous connection of the welding current. Both methods for the ignition of the welding arc do not cause inclusions in the welding bath or the wear of the electrode. LIFT ignition method generates significantly reduced interfering signals. Pure, non-melting tungsten electrodes are used for arc welding by direct current and alternating current. Carbon electrodes are used for arc welding of copper in a protective nitrogen atmosphere. Wolfram Inert Gas (WIG) welding is another name for gas tungsten arc welding. The advantages of TIG welding include high quality of the weld joints and weld deposits, suitability for welding thin materials and materials that are difficult to weld, suitability for welding in forced positions, e.g. when welding pipes, the possibility of automation and robotics. When welding thicker materials, lower labour productivity due to lower melting performance compared to melting electrode welding should be expected. Figure 2 shows the principle of TIG welding $[6,8]$.
1. Inert gas
2. Welding arc
3. Added material
4. Welding bath
5. Chuck
6. Wolfram electrode
7. Welded material

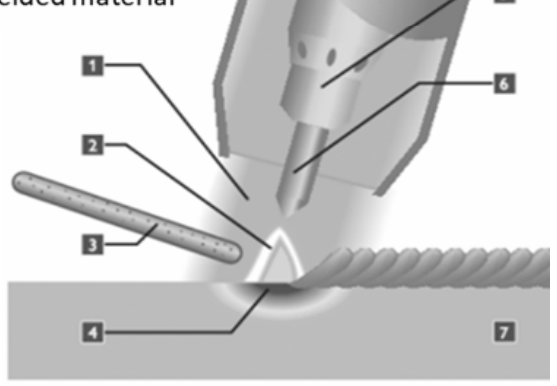

Figure 2. TIG welding process

Three main types of weld types and joints are used on welded pipes: butt weld, flange weld and unsupported flange weld (Figure 3).
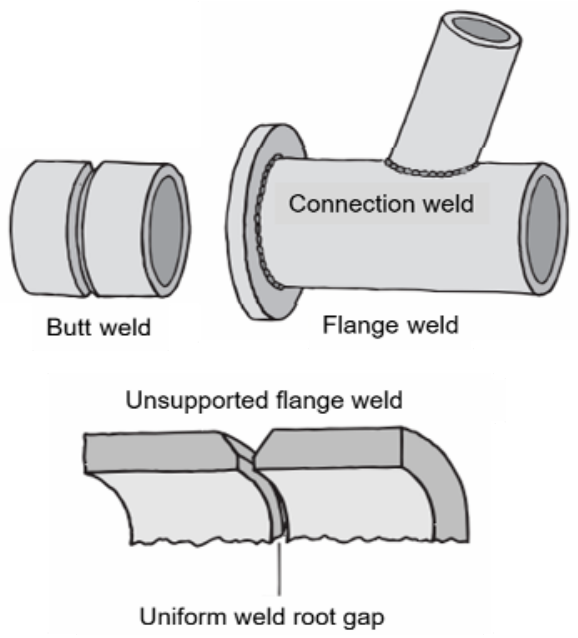

Figure 3. Different types of the weld joints on welded pipes

The weld joint can be divided into three basic areas according to the maximum temperature:

a) Weld metal,

b) Heat Affected Zone (HAZ),

c) Unaffected base material zone - parent metal.

Welding faults and defects are an unwanted but inseparable part of making weld joints. The aim is eliminating their occurrence.

Many factors influence the selection of a welding process, which contributes to the occurrence of welding faults and defects $[9,10]$. Standard ISO 6520-1:2007 Welding and allied processes. Classification of geometric imperfections in metallic materials. Part 1: Fusion welding [11] states that the imperfections are any deviation from the ideal weld and defects are an unacceptable imper- 
fection. As per [11] welding discontinuities are divided in following six groups:

1. Cracks,

2. Cavities,

3. Solid inclusions,

4. Lack of fusion and penetration,

5. Imperfecta shape and dimension,

6. Miscellaneous imperfection.

Welding defects can be classified in to two types as external and internal defects. External welding defects occur on the upper surface of the welded work. Surface defects of the weld joints are detected by the naked eye or by aid of tools such as magnifying glasses. Internal welding defects occur under the surface of the welded work. These can be detected only after metallographic preparation of the weld joint samples [12].

The main groups of welding defects are indicated by 3-digit numbers (e.g. 100 - Crack, 101 - Longitudinal crack). Subgroup specifying the welding defects in more detail are indicated by 4-digit numbers (1011 - Longitudinal crack in the weld metal, 1014 - Longitudinal crack in the parent metal) $[7,11,13]$. Figure 4 shows typical types of defects of the weld joints [14].

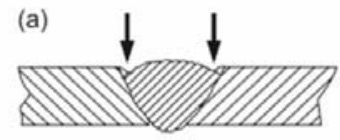

Undercut

(c)

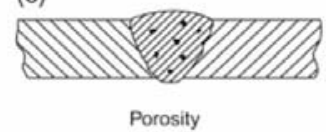

(e)

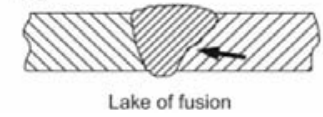

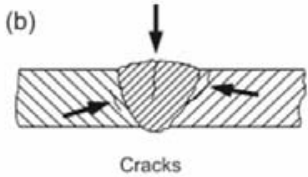

(d)

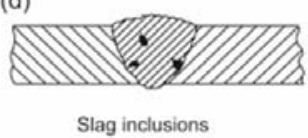

(f)

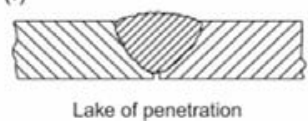

Figure 4. Different types of welding defects [14]

In standard ISO 5817:2008-03 [15] Arc-welded joints in steel. Guidance on quality levels for imperfections, three quality levels of the weld joints are described:

D - Lowest quality level,

C - Medium quality level,

B - Highest quality level.

The presence of the crack (100) is not acceptable in any of the quality levels.

Weld testing is used to assure the quality and correctness of the weld after it is completed. It is also necessary to check the materials before the process of welding [16].

Two types of tests determine the mechanical properties and quality of the weld joints. They are:

1. Destructive tests - metallographic analysis- microscopic, macroscopic, tensile strength tests, bend tests, hardness tests, Charpy impact tests, weld bending test etc.

2. Non-destructive methods - defectoscopic include visual testing, magnetic particle, liquid penetrant, eddy current, ultrasonic tests, X-ray testing etc.

The quality of welds is assessed in welded metal, heat affected zone (HAZ) and in unaffected base metal $[17,18]$.
The welds can be assessed not only by technical possibilities, but also by quality management methods. These do not detect faults and defects of the weld joints directly, but they significantly contribute to the discovery of the causes of their formation, resp. evaluation of their quantity. Such methods include the Ishikawa diagram - cause and effect diagram. It is a tool that allows visual representation of the factors that might contribute to an observed effect or phenomenon that is being examined. This method is universal and can be used in almost all areas of human activity. It solves design, technological, organizational, economic, social problems and other. In its theoretical essence, it is a method for analysing process variability. The purpose of the diagram is to point out the relationships between causes and effects (consequences) [19,20].

The Pareto analysis makes it possible to separate the important factors of the certain problem from those less essential, and to show in which direction to focus efforts in eliminating shortcomings in the quality assurance process. For most phenomena, we encounter two groups of influences. The first group is characterized by the fact that a small group of influences acts on the studied phenomenon in a decisive way - "vital minority". The second group has the opposite effect, although it is larger, the final effect on the studied phenomenon is insignificant - "trivial majority" or "useful majority" [20]. As stated by the authors [2, 21], it is necessary to evaluate the overall quality strategy in a new practical approach to improve the reliability of products in the automotive and aerospace industries. This is possible by using appropriate quality assurance tools - Ishikawa diagram and Pareto analyzes.

\section{EXPERIMENT}

The company for welding steel pipes is mainly focused on engineering activities, complex assemblies (boilers, connecting pipes and steel structures), repairs, reconstructions and supplies oriented in the industrial energy, chemical and petrochemical industries. The material of the pipes used for the experiment on which the weld joints were assessed is austenitic steel X2CrNi1911 (1.4306).

The chemical composition is in Table 1. Increased corrosion resistance characterizes the material.

The filler metals chosen for the welding pipes were selected according to the basic requirements to create high quality of the weld joints.

Table 1. Technical composition of the base material X2CrNi19-11 (wt. \%)

\begin{tabular}{|l|c|}
\hline Element & Composition (wt. \%) \\
\hline Carbon $(\mathrm{C})$ & 0.030 \\
\hline Silicon $(\mathrm{Si})$ & max. 1.50 \\
\hline Manganese $(\mathrm{Mn})$ & max. 2.00 \\
\hline Phosphorus $(\mathrm{P})$ & max. 0.035 \\
\hline Sulfur $(\mathrm{S})$ & max. 0.025 \\
\hline Chromium $(\mathrm{Cr})$ & $18.00-20.00$ \\
\hline Nickel $(\mathrm{Ni})$ & $9.00-12.00$ \\
\hline Nitrogen $(\mathrm{N})$ & max. 0.20 \\
\hline Iron $(\mathrm{Fe})$ & Rest \\
\hline
\end{tabular}


The values of mechanical properties of steel at normal temperatures are $R_{p} 1,0=210 \mathrm{MPa}, R_{m}=440-640$ $\mathrm{MPa}$ and $A=30 \%$. As the operating temperatures increase, the yield strength values $R_{p} 1,0$ decrease. At temperature $T=100{ }^{\circ} \mathrm{C}$ the yield strength value is $R_{p} 1,0$ $=165 \mathrm{MPa}$ and at max. temperature $T=350{ }^{\circ} \mathrm{C}$ is the value $R_{p} 1,0=100 \mathrm{MPa}$. The value of impact work is $K V$
$=80 \mathrm{~J}$. The Brinell hardness value is $130-200 \mathrm{HB}$. The steel is suitable for welding without further heat treatment of the weld joints.

A welding procedure specification has been developed for the welding pipes. Table 2 lists the welding parameters.

Table 2. Welding parameters for welding procedure specification

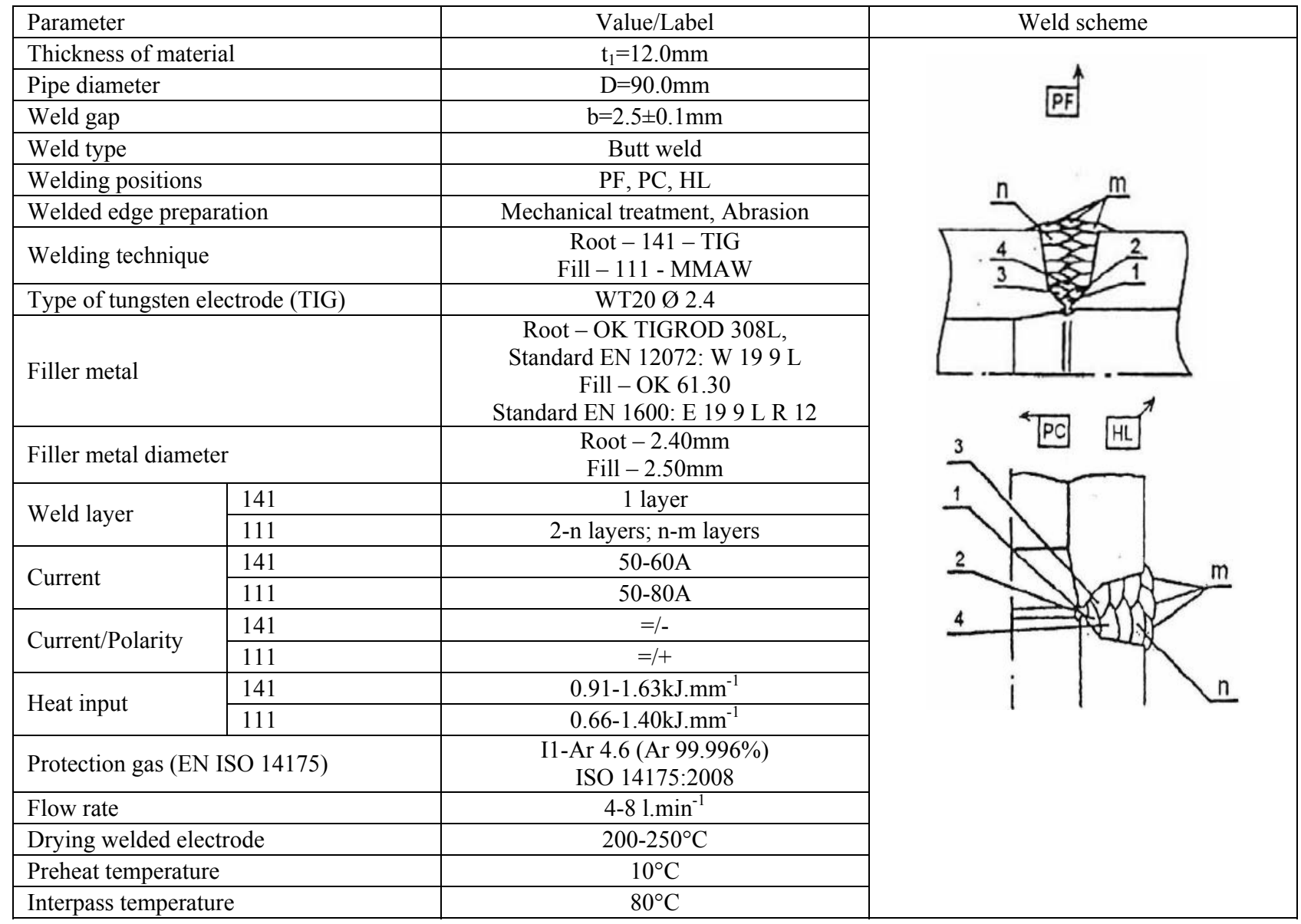

This mainly concerns the same or similar chemical composition as the basic material, the purpose for which the weld joint will serve, its load in operation, affordability, etc. [21].

Table 3. Chemical composition of the filler metal (wt. \%)

\begin{tabular}{|l|c|c|}
\hline \multirow{2}{*}{ Element } & \multicolumn{2}{|c|}{ Composition (wt. \%) } \\
\cline { 2 - 3 } & OK TIGROD 308L & OK 61.30 \\
\hline Carbon $(\mathrm{C})$ & $<0.003$ & $<0.003$ \\
\hline Silicon $(\mathrm{Si})$ & 0.40 & 0.70 \\
\hline Manganese $(\mathrm{Mn})$ & 1.80 & 0.80 \\
\hline Chromium $(\mathrm{Cr})$ & 20.0 & 19.5 \\
\hline Nickel $(\mathrm{Ni})$ & 10.0 & 10.0 \\
\hline Iron $(\mathrm{Fe})$ & Rest & Rest \\
\hline
\end{tabular}

Table 3 shows the chemical composition of the filler metal that was used to form the weld joint of the pipes.

The OK TIGROD 308L stainless steel wire is designed for welding austenitic stainless steel with a low carbon content which makes it particularly recommended when there is a risk of intergranular corrosion. It is widely used in the energy, chemical and food processing, industries for welding piping systems and vessels.
The OK61.30 stainless steel electrode is acid-rutile type with low carbon content designed for welding steels of the 19Cr10Ni-type. Also suitable for welding stabilized stainless steels of similar composition. The low-moisture casing provides high-quality weld metal and excellent weldability in all position.

It is suitable for welding steel e.g. W.Nr. 1.4000, $1.4301,1.4306,1.4308,1.4311,1.4541,1.4550$ and other. Figure 5 shows a sample of the welded pipe.

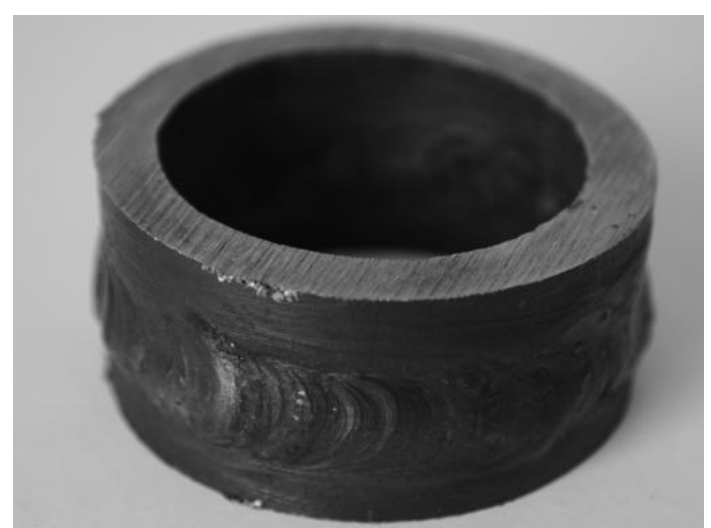

Figure 5. Sample of the welded pipe 


\section{RESULTS AND DISCUSSION}

\subsection{Quality evaluation of the weld joints - Technical methods}

The STEMI 2000 stereomicroscope from Zeiss (Figure 6 ) was used to identify, classify and evaluate faults and defects. Stereomicroscope images were processed using Mikrometrics 122U software.

Welding defects were visually observed from the outside and, after the pipes cut, from the inside of the pipe at 10x magnification. In Figure 7,8 and 9 are examples of observed welds. Mainly, defects in the shape and dimensions of the welds were visually observed.

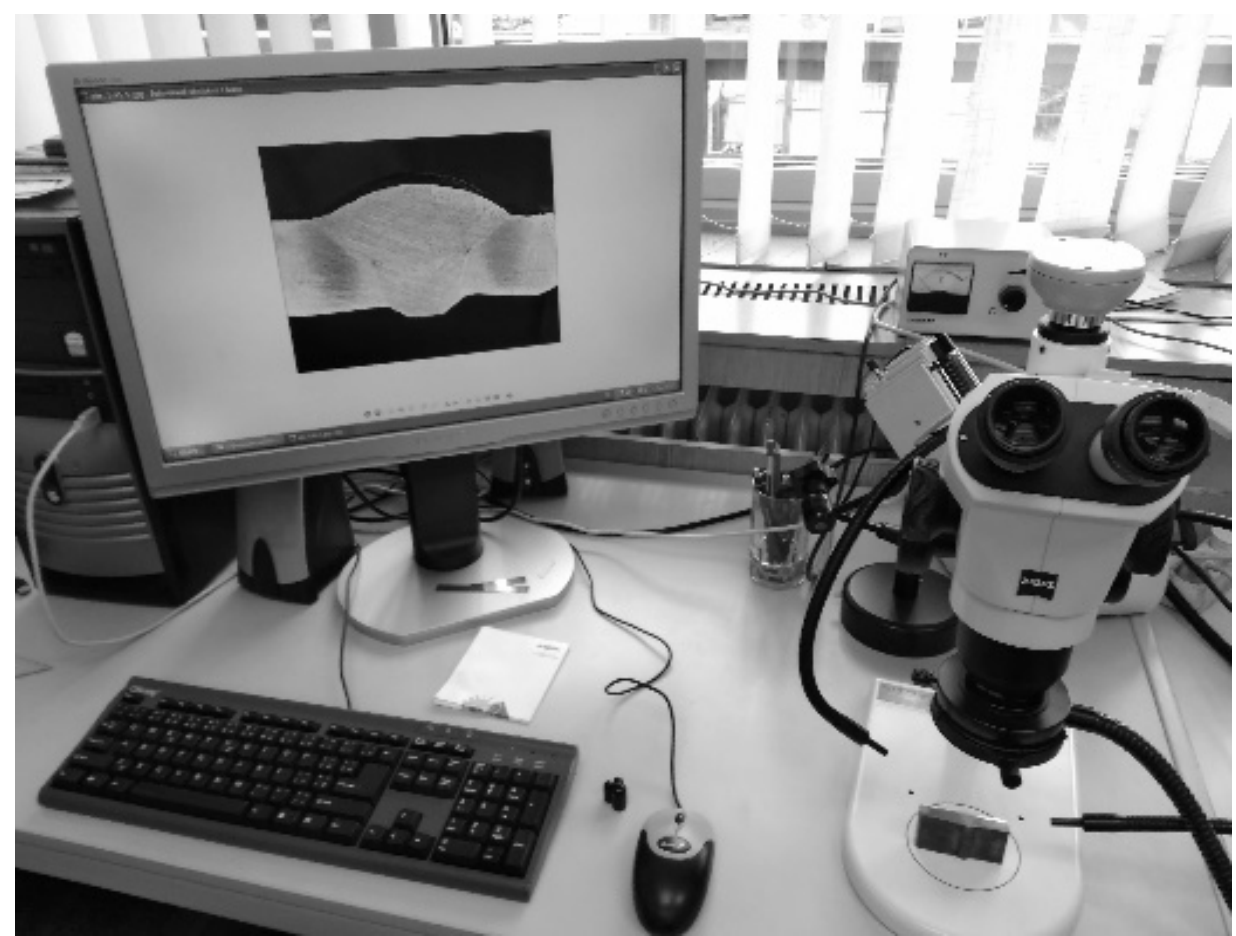

Figure 6. Observation and evaluation of the quality of the weld joints
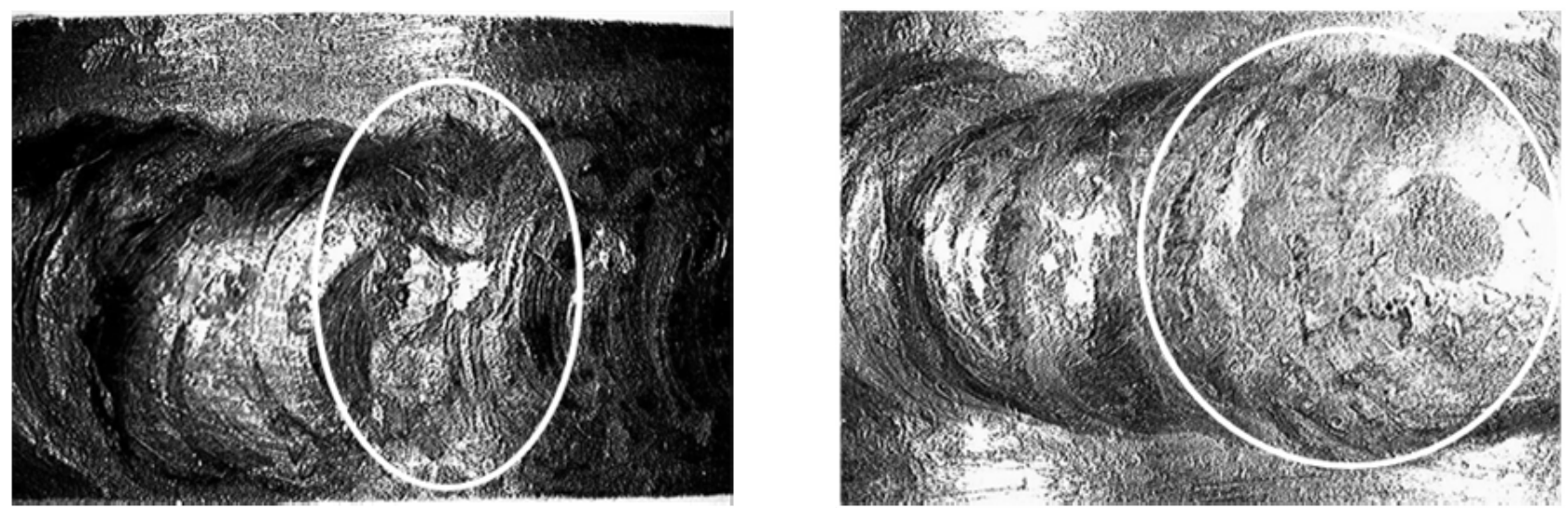

Figure 7. Observation of the defects from the outside of the pipes
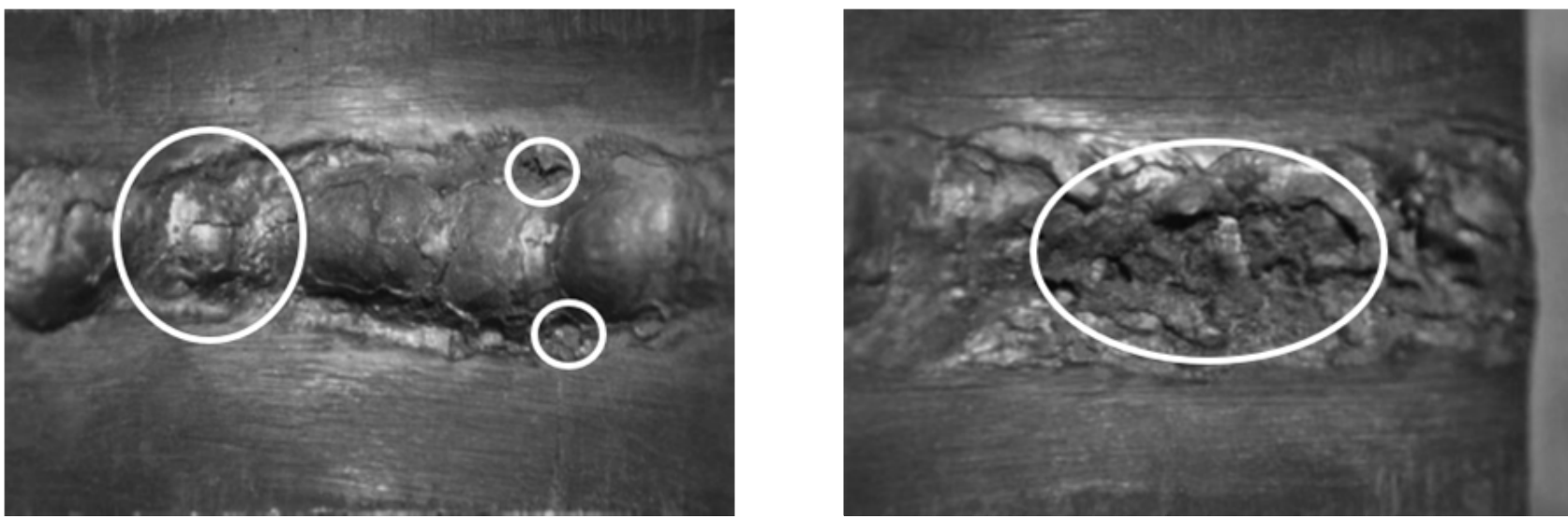

Figure 8. Observation of the defects from inside of the pipes 


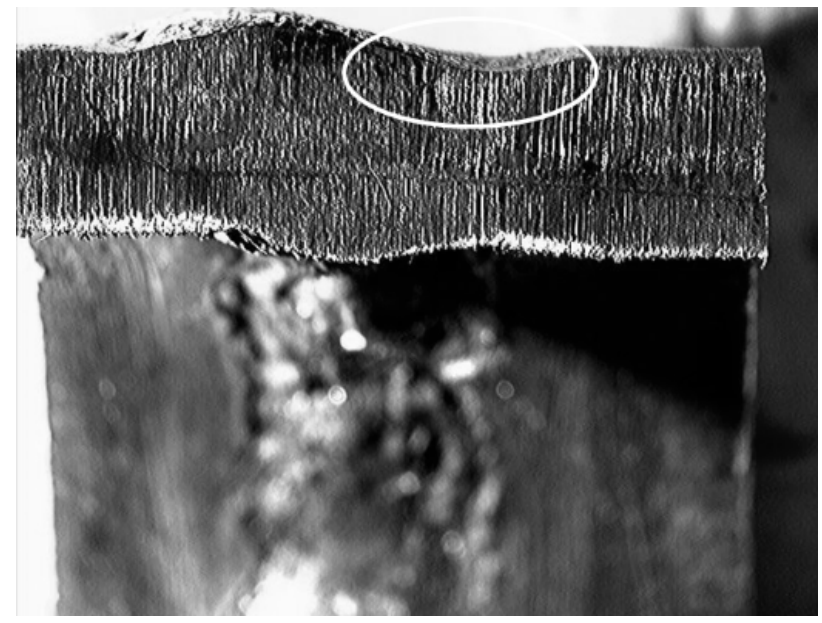

Figure 9. Observation of the defects on welded pipe section

These defects were not assessed separately in the experiment. We focused on the evaluation of internal defects on prepared sections of the weld joints by metallographic analysis - Macroscopic examination.

The samples were prepared for examination by standard metallographic methods - grinded wet by sanding papers with a grain size of 180 to 600 and etched in $2 \%$ Nital Etch.

The standard ISO 6520-1:2007 was used for classification of geometric imperfections in weld joints of the pipes made by fusion welding. In Figure 10 are examples failures and defects that have been identified at 16.6x magnification of the weld joints. Figure 10a

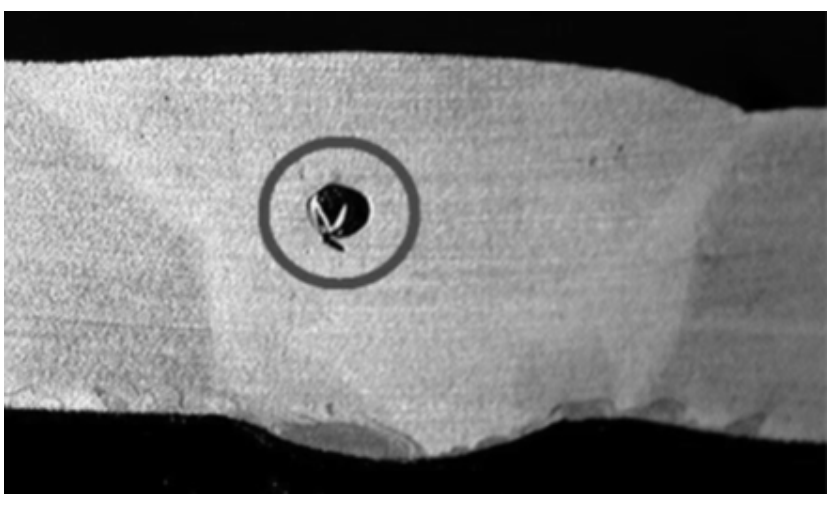

a

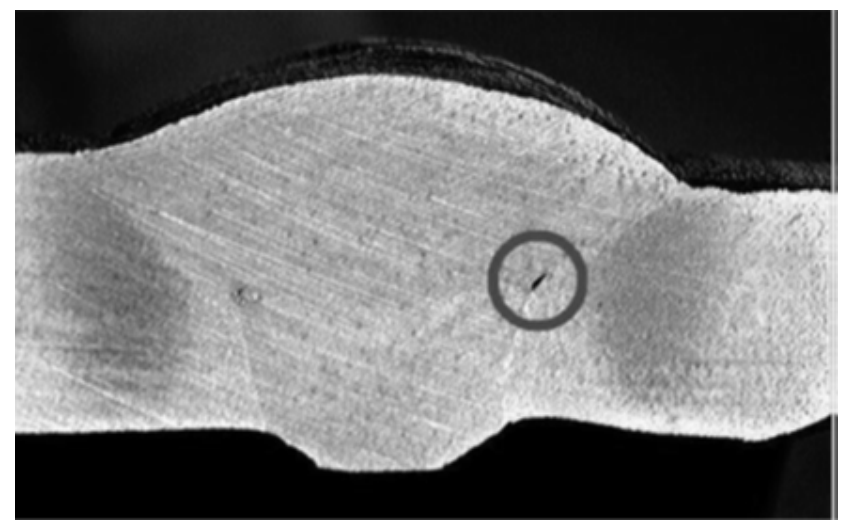

C shows a defect from a group 200 - Cavities (2011). In figure $10 \mathrm{~b}$ is defect from a group 300 - Solid inclusion representing a solid foreign substance trapped in the weld metal (301).

The Lack of fusion and penetration from group 4 (classified under number 4012) is shown in Figure 10c. Figure 10d shows the defect from group 5, classified as Sagging - caused by gravity (5092). No defects from group 1 - Crack and 6 - Miscellaneous imperfections were found on the welds.

\subsection{Management methods for quality evaluation of the weld joints}

The cause and effect diagram was used to identify the causes of welding defects divided into the five main categories. Based on the facts found in operation, we constructed the diagram shown in Figure 11.

The Pareto diagram was used to determine the occurrence of welding defects during macroscopic examination of the weld joints. Before creating the diagram, a table of occurrence defects (Table 4) was created.

The faults and defects of the weld joints sorted by frequency of occurrences in descending order are presented in Table 5. The individual frequency was assigned to the individual defects and total cumulative frequency in percent was calculated from this.

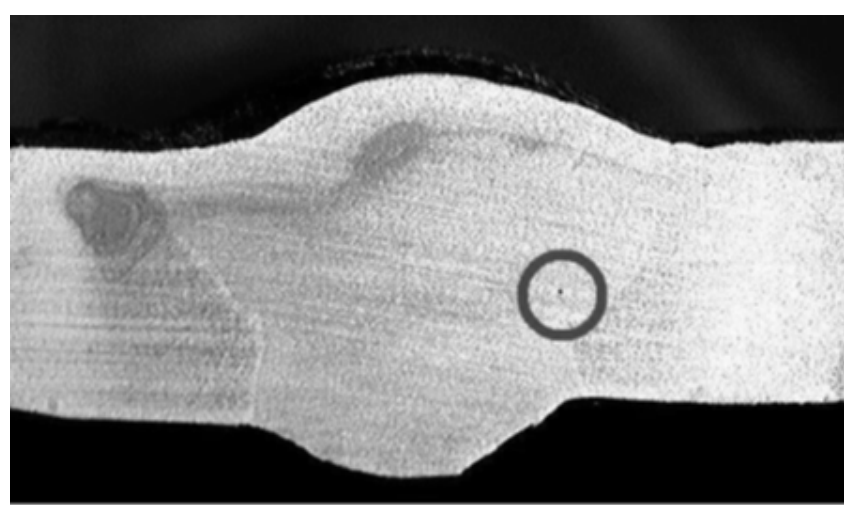

b

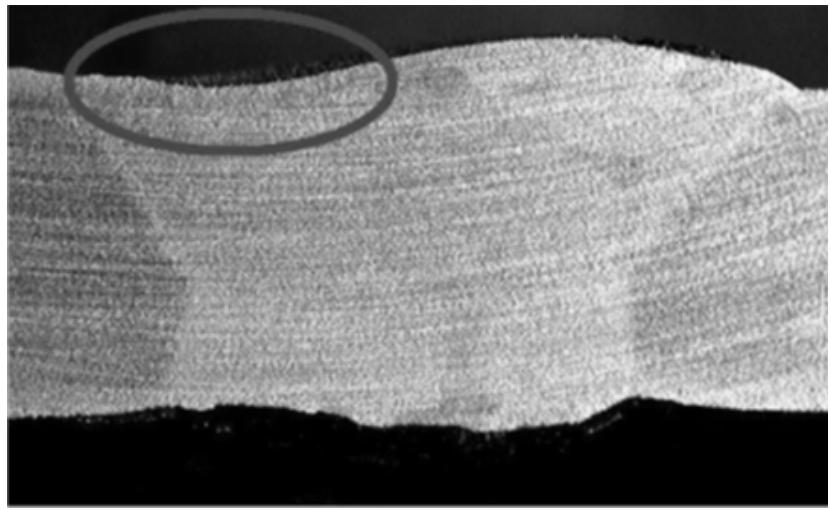

d

Figure 10. Detected failures and defects on weld joints of the pipes 


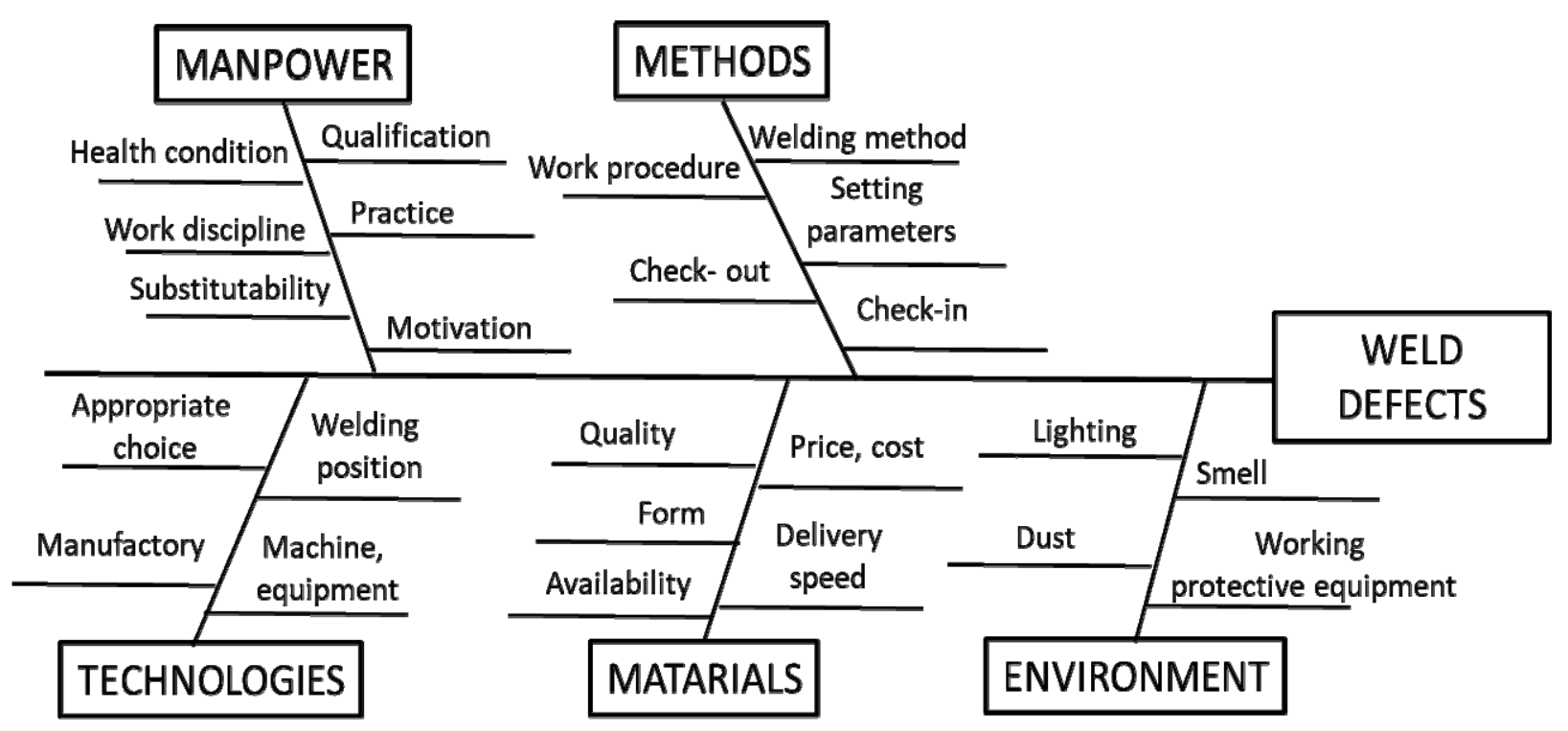

Figure 11. Cause and effect diagram

Table 4. Occurrence of identified welding defects

\begin{tabular}{|l|c|c|}
\hline Description - Type of Weld Defect & $\begin{array}{c}\text { Defect in accordance with } \\
\text { ISO 6520-1:2007 }\end{array}$ \\
\hline Cavity & 2011 & Occurrence - number \\
\hline Solid inclusion & 300 & 16 \\
\hline Lack of fusion & 401 & 11 \\
\hline Shrinkage groove & 5013 & 8 \\
\hline Sagging & 5092 & 6 \\
\hline Root concavity & 515 & 3 \\
\hline Toe overlap & 5061 & 2 \\
\hline
\end{tabular}

Table 5. Table for creating a Pareto diagram

\begin{tabular}{|l|l|c|c|c|c|}
\hline $\begin{array}{c}\text { Number } \\
k\end{array}$ & $\begin{array}{c}\text { Description - Type of Weld } \\
\text { Defect }\end{array}$ & $\begin{array}{c}\text { Frequency } \\
\text { of Occurrence } n\end{array}$ & $\begin{array}{c}\text { Cumulative } \\
\text { Frequency } \Sigma n\end{array}$ & $\begin{array}{c}\text { Individual } \\
\text { Percentage \% }\end{array}$ & $\begin{array}{c}\text { Cumulative } \\
\text { Percentage } \Sigma \%\end{array}$ \\
\hline 1 & Cavity & 16 & 16 & 26.6 & 26.6 \\
\hline 2 & Solid inclusion & 14 & 30 & 23.3 & 50.0 \\
\hline 3 & Lack of fusion & 11 & 41 & 18.3 & 68.3 \\
\hline 4 & Shrinkage groove & 7 & 48 & 13.3 & 81.6 \\
\hline 5 & Sagging & 6 & 54 & 10.0 & 91.6 \\
\hline 6 & Root concavity & 3 & 57 & 5.0 & 96.6 \\
\hline 7 & Toe overlap & 3 & 60 & 3.3 & 100.0 \\
\hline
\end{tabular}

A breakpoint $B_{p}(\%)$ is looking for when interpreting a Pareto diagram. This point should confirm or refute the presumption of the importance of focusing defects on improving the quality of the weld joints [20]. It is calculated according to the formula (1):

$$
\mathrm{B}_{\mathrm{P}}=\frac{\sum \mathrm{n}}{\mathrm{k}}=\frac{60}{7}=8.6 \%
$$

The result shows that the first three types of welding defects are higher than $8.6 \%$. It is therefore the „vital minority“. Others can be considered a "useful majority". These are all from defects group 5 - Imperfecta shape and dimension.

Based on the table, a Pareto diagram was created, graphically showing the frequency of the occurrence of individual defects that were found during the inspection of the weld joints. Pareto diagram and the Lorenz curve represents the cumulative sum of the occurrences of individual causes (Figure 12).
To obtain a high quality of the weld joints means to harmonize a suitable filler material to the base material, alto to design a suitable welding method as well as welding conditions and quality of welders in accordance with applicable European standards [16,7].

According to standard ISO 5817:2008-03 we can state that in most of the evaluated welds a lowest (D) to medium quality level (C) was achieved. However, for a given type of the weld joints, it is assumed to achieve quality level D - highest quality level.

The results of the Ishikawa diagram show that all five categories need to be observed. In the Manpower category, it is the qualification of welders trained according to standard ISO 9606-1:2017 [22, 23]. Therefore, it is necessary to ensure their regular retraining. Their sufficient motivation and overall work discipline are also important. Maintaining quality is very difficult to achieve with high fluctuations. Compliance with working procedures according to approved welding pro- 


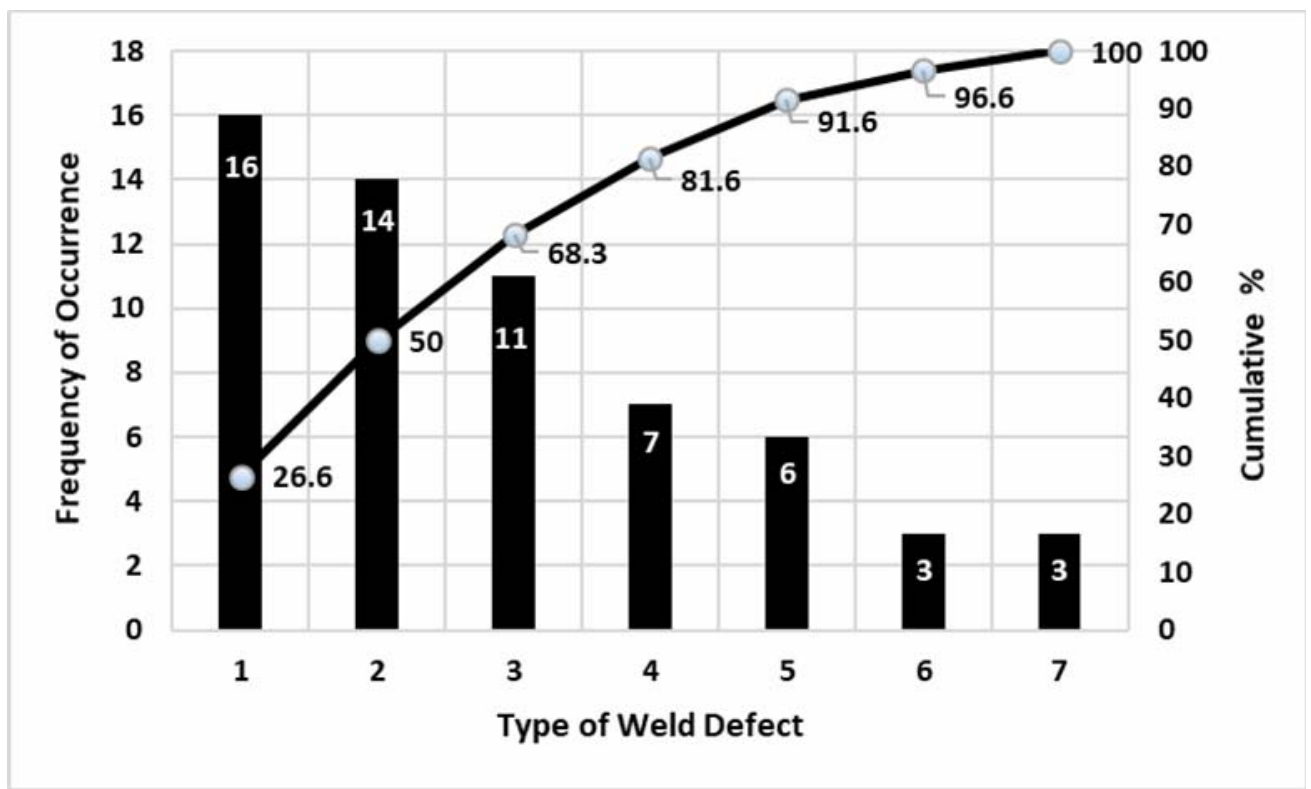

Figure 12. Pareto diagram with Lorenz curve

cedures (WPQR) based on previous experience approved by accredited institutions should be checked when assessing the Methods category. All this provided that the Preliminary Welding Procedure (pWPS) has been developed correctly. The work environment in which welders work for several hours a day is also an important category. If welding is done indoor, it is necessary to ensure ventilation, proper lighting and to ensure quality personal or collective protective equipment.

It is clear from the results of the Pareto analysis that the vital minority of welding defects were from three different group - cavity, solid inclusion and lack of fusion. The TIG method should be used to eliminate them - inside of the pipe should be filled with argon or nitrogen in order to protect the bottom layer of the weld root and to form its profile. A combination of TIG and MIG/MAG welding methods can also be chosen $[6,24]$.

Achieving and maintaining good quality of the weld joints can only be achieved with correctly set welding parameters, especially it is the welding current, voltage or compliance with the electrodes drying time [12]. It is possible to used some simulation modelling. As stated in [25] the mathematical model was developed using MATLAB tool to further predict the temperature distribution and total stress concentration at any localized nodal point. The model can be used to obtain optimal weld parameters such as weld, speed torch temperature, current and voltage.The residual stress was predicted through a model of the multi-pass girth weld joint using Finite Element Method (FEM) [26,27].

\section{CONCLUSION}

The combination of various methods for evaluating the quality of the weld joints of the pipes was to reveal the causes of failures and defects and offer solutions to increase the quality of the weld joints.

By technical methods we are able to identify welding defects on the macrostructures of welds using stereomicroscope. According to valid standards [11, 15], we detected them and classified into the groups, classes and subgroups.
The use of the cause and effect diagram allowed us to identify the causes of welding defects evaluated in five main categories. Significant secondary causes can be considered the right choice of welding process, compliance with WPWS, skills and experience of welders, inspection of the weld joints and working conditions during welding.

From the detection and classification of welding defects, we created the Pareto diagram which helped us to identify the three most common types of welding defects (vital minority) affecting the overall quality of welding steel pipes.

Combination of technical and management methods and tools offers a view of the issue from a broader angle. This presupposes that the problems that have arisen will be solved more comprehensively.

\section{REFERENCES}

[1] Cierna, H., Sujová, E. and Ťavodová, M.: Selected aspects of management for technicians. Zvolen, Technical University in Zvolen, 2015.

[2] Fragassa, C., Pavlovic, A., Massimo, S.: Using a Total Quality Strategy in a new Practical Approach for Improving the Product Reliability in Automotive Industry, in: International Journal for Quality Research, Vol. 8, No. 3, pp. 297-310, 2014.

[3] Lukic, L., Djapic, M., Fragassa, C., Petrovic, A., Pavlovic, A.: Optimization Model for Machining Processes Design in Flexible Manufacturing Systems, in: Journal of Advanced Manufacturing Systems, Vol. 17, No. 2, pp. 137-153, 2018.

[4] Drbúl, M., Stančeková, D., Babík, O., Holubjak, J., Görögová, I. and Varga D.: Simulation Possibilities of 3D Measuring in Progressive Control of Production, in: Manufacturing technology, Vol. 17, No. 1, pp. 53-58, 2017.

[5] Fragassa, C.: Material selection in machine design: The change of cast iron for improving the highquality in woodworking. Proceedings of the Institution of Mechanical Engineers, Part C: Journal 
of Mechanical Engineering Science, Vol. 231, No. 1, pp. 18-30, 2017.

[6] Országh, P. and Országh. V.: MMA Welding of steels and non-ferrous metals. Bratislava, VEDA, Vydavatel'stvo SAV, 2003. pp. 411.

[7] Bernát, R., Záležák, Z., Kecskés, N. and Blaško, P.: Assessing the Weld Quality of Manganese Steel, Acta Technologica Agriculturae, Vol. 16, No. 4, pp. 99-102, 2013.

[8] Országh, P. and Országh. V.: MIG/MAG Welding of steels and non-ferrous metals. (Zváranie MIG/MAG ocelí a neželezných kovov). Bratislava Polygrafia SAV, 2000. pp.460.

[9] Paredes, M. and Ruggieri C.: Engineering approach for circumferential flaws in girth weld pipes subjected to bending load, International Journal of Pressure Vessels \& Piping, Vol. 125, No. 3, pp. 4965, 2015.

[10] Kováč, I., Mikuš, R., Žarnovský, J., Drlička, R., Žitňanský, J. and Výrostková, A.: Creation of wear resistant boride layers on selected steel grades in electric arc remelting process, Metallic Materials, Vol. 52, No. 6, pp. 387-394, 2014.

[11] ISO 6520-1:2007: Welding and allied processes. Classification of geometric imperfections in metallic materials. Part 1: Fusion welding.

[12] Ťavodová, M., Hnilicová, M. and Švantner T.: Proposal of use of welded joints EN AW-6082 for adapters of forest technic, Manufacturing technology, Vol. 19, pp. 706-711, Aug. 2019.

[13] Budiono, Y. K. and Martowibowo, S. Y.: Optimization of Resistance Spot Welding Process using Response Surface Methodology and Simulated Annealing, Manufacturing technology, Vol. 17, No. 4., pp. 434-440, 2017.

[14] Chen, M. J., Dong, G., Jakobsen, R. A. and Bai, Y.: Assessment of Pipeline Girth Weld Defects, in: The Tenth International Offshore and Polar Engineering Conference, 28.05-02.06.2000, Seattle, US. https://www.onepetro.org/conference-paper/ISOPE -I-00-149.

[15] ISO 5817:2008-03: Arc-welded joints in steel. Guidance on quality levels for imperfections.

[16] Svobodova, J.: Failures Caused by Heat Treatment and Their Identification, Manufacturing Technology, Vol. 17, No. 6., pp. 969-972, 2017.

[17] Patek, M. et al.: Destructive testing of the weld joints on split sleeve for branch connections repairs, Communications, Vol. 4, pp. 65-69, 2015.

[18] Li, Y., Shuai, J. and Xu, K.: Investigation on size tolerance of pore defect of girth weld pipe, PLoS ONE, Vol. 13, Iss. 1, No. e0191575, 2018.

[19] Sujová, E. and Čierna, H.: Optimization and improvement of test processes on a production line, Management systems in production engineering, Vol. 26, pp. 88-92, 2018.
[20] Powell, T. and Sammut-Bonnici, T.: Pareto analysis, In: Wiley Encyclopedia of Management Vol 12 Strategic Management, 2015.

[21] Rašuo, B. and Djuknić, G: Optimization of the aircraft general overhaul process, Aircraft Engineering and Aerospace Technology, Vol. 85, No. 5, pp. 343-354. 2013.

[22] Sadowski, A. et al.: Harmonic analysis of measured initial geometric imperfections in large spiral welded carbon steel tubes, Engineering Structures, Vol. 85(C), pp. 234-248, 2015.

[23] Singh. R.: Applied Welding Engineering Processes, Codes, and Standards. (2nd edition). Elsevier, 2016. DOI: 10.1016/C2015-0-00784-5.

[24] ISO 9606-1:2017 Qualification test of welders. Fusion welding. Part 1: Steels.

[25] Kiran, B., Mishra, K., Singh, Y.R. Nagaraju, D.: Structural and thermal analysis of butt joint GTAW of similar and dissimilar materials with distinct groove angles through simulation and mathematical modelling, FME Transactions, Vol. 48, No. 3, pp. 667-680, 2020.

[26] Darmadi, D.B.: Incorporating aged martensite model in residual stress prediction of ferritic steels girth weld, FME Transactions, Vol. 47, No. 4, pp. 901-913, 2019.

[27] Perić, M., Tonković, Z., Maksimović, K.S. and Stamenković, D.: Numerical analysis of residual stresses in a T-Joint fillet weld using a submodeling technique. FME Transactions, Vol. 47, No. 1, pp. 183-189, 2019.

\section{ПРОЦЕНА КВАЛИТЕТА ЗАВАРИВАЊА ЗАВАРЕНИХ СПОЈЕВА У ИНДУСТРИЈСКИМ ЦЕВИМА}

\section{М. Таводова, Н. Напрсткова, М. Хлиницова, П. Бено}

Овај рад истражује поступке за процену квалитета заварених спојева у случају заварених цеви које се користе у индустријском енергетском сектору. Кварови и недостаци заваривања прво су испитани и идентификовани металографском анализом заварених макроструктура. Следеће су раздвојене и сврстане у категорије нивоа квалитета у складу са ИСО 6520-1: 2007 и ИСО 5817-3: 2008. Затим су узети у обзир дијаграм узрока и последица Ишикава и Парето дијаграм за процену квалитета заваривања. Ова два алата за квалитетне менаџере омогус́ила су препознавање најозбиљнијих грешака и недостатака заваривања, али и њихово повезивање са њиховим специфичним узроцима. Поред тога, ови алати дозвољавају утврђивање учесталости појављивања кварова. Коначно, обе методе откриле су недостатке у техничким и технолошким областима и особљу, што је омогућило побољшање процеса заваривања цеви у раду и већу сигурност цевних система. 